INTERDISCIPLINARIA ARCHAEOLOGICA

A look at the region

\title{
VIAS - the Vienna Institute for Archaeological Science
}

\author{
Irmgard Hein ${ }^{* 1,2}$, Birgit Bühler ${ }^{1}$, Maria Ivanova-Bieg ${ }^{1}$, Günther-Karl Kunst ${ }^{1}$, Mathias Mehofer ${ }^{1}$, \\ Gabriele Scharrer-Liska ${ }^{1}$, Wolfgang Lobisser ${ }^{1}$, Wolfgang Neubauer ${ }^{1,3}$, Immo Trinks $^{1,3}$ \\ ${ }^{I}$ VIAS, Vienna Institute for Archaeological Science, Franz-Klein-G. 1, A-1190 Vienna. Austria \\ ${ }^{2}$ Institute for Egyptology, University Vienna, Franz-Klein-G. 1, A-1190 Vienna. Austria \\ ${ }^{3}$ Ludwig Boltzmann Institute for Archaeological Prospection and Virtual Archaeology. Hohe Warte 38, A-1190 Vienna, Austria
}

\section{ARTICLE INFO}

\section{Article history:}

Received: $20^{\text {th }}$ December 2020

Accepted: $28^{\text {th }}$ January 2021

DOI: http://dx.doi.org/10.24916/iansa.2021.1.6

\section{Key words:}

archaeozoology

bioarchaeology

archaeometry and archaeometallurgy

analysis of precious metals

ceramology

geophysical archaeological prospection on land

and underwater

geoarchaeology

digital archaeological documentation methods

experimental archaeology

\begin{abstract}
A B S T R A C T
The Vienna Institute for Archaeological Science (VIAS) was founded within the University of Vienna in 1992 as a forward-looking transdisciplinary institution. VIAS aims to develop and integrate methods from the natural sciences in a dynamic relationship with the culture-oriented investigative frameworks of archaeology, and to provide support, knowledge and partnership in multidisciplinary research programmes and projects.

VIAS functions as a core facility and it is conducting research in the fields of archaeobotany, archaeozoology, bioarchaeology, archaeometry and archaeometallurgy, analysis of precious metals, ceramology, geophysical archaeological prospection on land and underwater, geoarchaeology, digital archaeological documentation methods, and experimental archaeology.

VIAS reaches out beyond the university by developing and collaborating in projects together with the Austrian Academy of Sciences and regional museums and cultural heritage administrations as well as many international partners. VIAS has substantially contributed to the development of efficient high-resolution prospection methods as a founding partner in the Ludwig Boltzmann Institute for Archaeological Prospection and Virtual Archaeology.
\end{abstract}

\section{Development of the institute}

The Vienna Institute for Archaeological Science (VIAS) was founded in 1992, when the University of Vienna took the initiative for the first time in Austria to establish an „Interdisciplinary Institution for Archaeology” within the Faculty of Humanities. The intention of the founders was to create a future-oriented, transdisciplinary institution for science-focused, archaeological research subjects. New methods that have become available by technological advancements - in the analytical field as well as in the exploration and study of landscapes - were to be applied in archaeological research, and above all, developed further.

In 1998, the institution initially named IDEA was rebranded as VIAS, which in 2000 became an interdisciplinary research

*Corresponding author. E-mail: irmgard.hein@univie.ac.at institute, and subsequently from 2006-2013 functioned as an interdisciplinary research platform. Since then, VIAS has been established at the Faculty of Historical and Cultural Studies.

The management of VIAS was initially headed by the classical archaeologist Fritz Krinzinger, then in 1999, the medieval archaeologist Falko Daim took over the leadership until 2004 and pushed forward many new research impulses. From 2004 to 2011, the Egyptian archaeologist Manfred Bietak was in charge, followed by the prehistorians Michael Doneus until 2013, and then Tim Taylor. Since October 2020, geophysicist Immo Trinks is heading VIAS with Irmgard Hein and Wolfgang Neubauer as deputies.

Already the first phase of the institute was characterised by a combination of bioarchaeological and technically-oriented, research directions. The establishment of research projects from other interdisciplinary fields has led to the affiliation of further 
disciplines to VIAS. Currently, VIAS' fields of research cover archaeobotany, archaeozoology, bioarchaeology, archaeometry and archaeometallurgy, analysis of precious metals, ceramology, digital archaeological documentation methods, geophysical archaeological prospection on land and underwater, geoarchaeology, and experimental archaeology.

This wide-ranging combination of natural science-oriented subjects together with technically-oriented disciplines in association with a research institute for archaeology forms a dynamic basis for answering a wide range of archaeological questions. In the course of its research projects, various current issues and developments in archaeology form focal points, often in cooperation with regional museums and local authorities, which find solutions in the field of cultural heritage management. The broad reach of VIAS is reflected in its cooperation with numerous national and international research institutions, such as the Austrian Academy of Sciences, and museums.

VIAS is an important founding partner of the international Ludwig Boltzmann Institute for Archaeological Prospection and Virtual Archaeology (LBI ArchPro). In addition to large-scale motorised magnetometer measurements, highresolution ground-penetrating radar surveys, 3-D laser scanning (terrestrial and airborne) and state-of-the-art image-based 3-D documentation of archaeological sites, the LBI ArchPro is developing a new approach to underwater archaeological prospection using high-resolution multibeam and sediment sonar measurements in close cooperation with VIAS.

The following brief presentations of the individual departments provide an overview of the research potential of this core facility at the University of Vienna.

\section{Archaeozoology by Günther Karl Kunst}

As involvement in archaeological projects with a demanding stratigraphy is a central task of VIAS, so is Archaeozoology. Here, the record of animal bones can contribute decisively to the interpretation of archaeological features. Of special interest in this regard are multi-period sites, which undergo diachronic changes in function, including buildings with a complicated architectural history. Careful collection and archiving of animal remains, close communication with the scholars involved in the analysis of pottery and small finds, and a professional elaboration and documentation of the stratigraphy in an accessible database are necessary prerequisites for this type of research. A focus is placed on developed cultures of the Near East (Turkey, Egypt), on Roman provincial archaeology and on the Medieval (and early post-medieval) Archaeology of eastern Austria (Lower Austria, Burgenland). The archaeozoology branch of VIAS is currently involved in the following projects (partners): Nerik (Uşak University, FU Berlin), Orth an der Donau, Hornstein (Bundesdenkmalamt Wien), Burgstall Neudegg (VIAS internal), Carnuntum (Archäologischer Park Carnuntum). In particular in the research project focusing on the civilian city of Carnuntum, which also involves a recent $\mathrm{PhD}$ project (N.I. Kirchengast), a bottom-up (pattern-recognition) strategy is pursued: Which context types, and consequently, which types of animal bone assemblages do occur, where and why? This approach is meant as a step away from the naiveté of traditional, largely a-historic "bone counting and comparing" without any consideration of the respective archaeological setting. In this sense, at the ICAZ conference in Ankara 2018, together with the bioarchaeology group of the Austrian Academy of

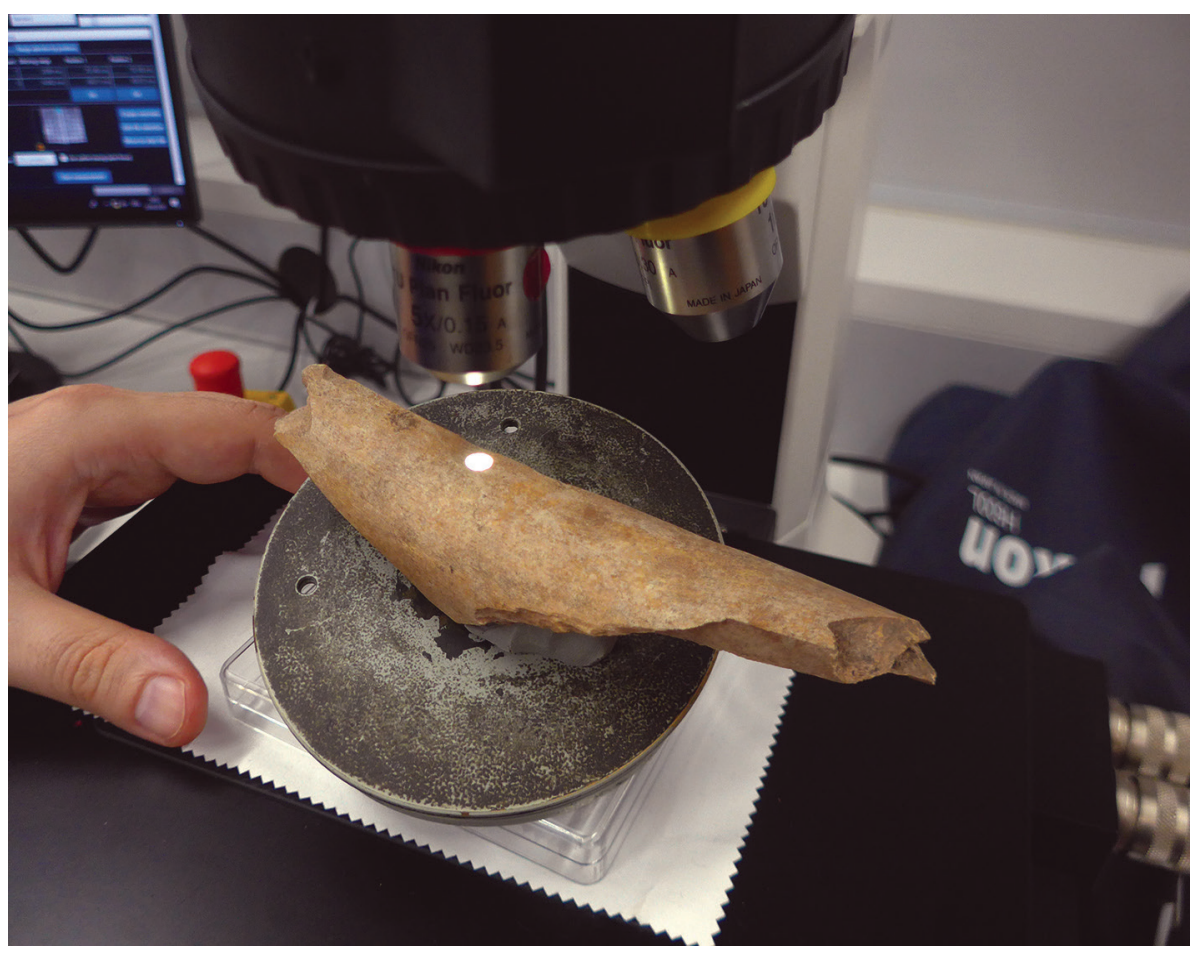

Figure 1. Using confocal microscopy for the analysis of surface marks on a Roman period cattle bone from Wels (Upper Austria). Photo by G. K. Kunst. 
Sciences (A. Galik), a session on the "taphonomy of buildings" was organized, the papers of which have already been published.

Another emphasis of VIAS' archaeozoology comprises butchery studies. Recently, confocal microscopy housed at the Institute for Palaeontology (D. Nagel, University of Vienna) has been tested for the assessment of chop marks on the surfaces of Roman cattle bones. The first results are promising. Further, the recently started project on the rich animal bone samples of the Late-La-Tène settlement of Traun (Upper Austria) will hopefully provide the long-awaited preRoman corner stone against which later developments in Roman butchery can be plotted. A planned session (together with K. Seetah and J. Turek) on the "Archaeology of Meat" at the WAC in Prague, scheduled for July 2020, had to be postponed to 2022 for obvious reasons.

VIAS' archaeozoology is also a partner in the following projects devoted to aDNA research: dispersion of the black rat in Europe, early history of the turkey in Europe, discrimination of horses and mules, and dispersion of the fallow deer.

\section{Bioarchaeology by Maria Ivanova-Bieg}

On-going research at the Bioarchaeology Department at VIAS concerns the processes that led to the foraging-to-farming transition and the growth of early agricultural societies in Europe. It is based on a combination of archaeological approaches to material culture and collaborations with the disciplines of archaeobotany, zooarchaeology, biogeography and biogeochemistry. My projects employ methods of organic residue analysis of pottery, stable isotope analysis of faunal and botanical remains, compound-specific radiocarbon dating, and agent-based modelling.
SUSTAIN. Sustainability of Agriculture In Neolithic Europe. Funded by an ERC Consolidator Grant. The aim of SUSTAIN is to elucidate how early agricultural societies in Europe maintained their capacity to self-generate and persist through time. The project weaves together various approaches from social anthropology, biogeography, bioarchaeology and complex science in a manner that has not been attempted previously. We will examine the relationship of domesticates' past range expansions and climate using correlative species distribution models and will derive past agro-pastoral practices from isotope signals in plant and animal remains. Novel approaches of quantitative inference will allow us to estimate parameters of crop and livestock productivity and to directly compare agro-pastoral performance across time and space in Europe. Using this knowledge, we will employ spatiallyexplicit, agent-based simulation to explore the social parameters of growth and decline of the first agricultural societies in Europe in previously unconsidered detail. The project will produce insights that challenge conventional wisdom about farming and environmental sustainability, particularly with regard to social connectedness, relations of sharing, and mobility, which will have value and impact beyond archaeology.

Project partners are the Senckenberg Biodiversity and Climate Research Centre; the School of Chemistry, University of Bristol; the National Museum of Natural Sciences/CNRS, Paris; the Laboratory of Archaeobotany at the State Office of Cultural Heritage, Stuttgart; the Research Department of Genetics, Evolution and Environment, UCL.

\section{Archaeometallurgy by Mathias Mehofer}

The Department of Archaeometallurgy of VIAS conducts intensive research in the field of archaeometric analysis of archaeological objects. The goal is the description of
Figure 2. ERC project SUSTAIN. Map of the project research area with the four case study regions.

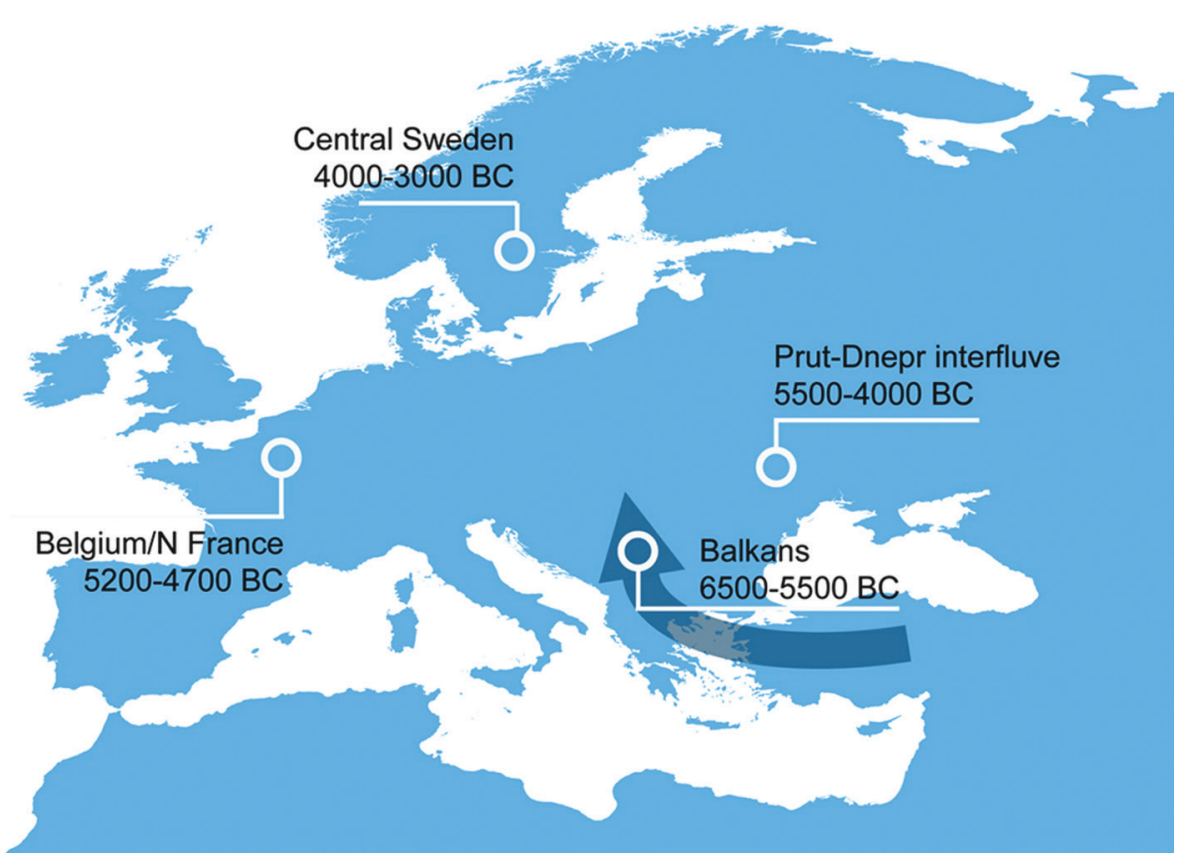


a complete technology chain (raw material processing - finished product - post-processing - reuse) as well as the documentation of the changes and influences on archaeological artefacts caused by the surrounding soil. The description, classification and typology of archaeological objects provides the basis for the treatment and processing of finds as well as for the reconstruction of prehistoric value and social systems. The metallurgical investigation and technological description of metal artefacts and the waste and by-products of their production (e.g. slag) allows for the description of the material processing as well as a determination of the quality of the raw materials used (alloy composition). By means of detailed archaeometallurgical analyses it is possible to gain insights into the technical structure of an object and its specific material qualities. Thus individual workshop circles, production centres and technology transfer can be derived. Based on these typological investigations on used technology, further insights into craft and forging technology of a certain period can be gained. In combination with historical sources, the results of these analyses also offer a deeper insight into prehistoric social systems. Another research focus in the field of metallurgy is the non-destructive analysis of precious metal and nonferrous metal objects using a Scanning Electron Microscope and energy dispersive $\mathrm{x}$-ray microanalysis. Priority is given to research on manufacturing techniques of artefacts, and the analysis of their chemical composition (main, secondary and trace elements), as well as the provenance of the metal (lead isotope analyses). The documentation of technological features allows for a reconstruction and description of the manufacturing process of individual objects, as well as the formation of groups based on technological criteria. These groups can be compared and correlated with the results of archaeological analyses and thereby permit the reconstruction of the technological development in certain periods.

\section{Ongoing projects:}

- Archaeometallurgical and mining archaeological studies on Bronze Age metallurgy in the Western Balkans (FWF project P 32095).

- War and peace between Mycenaean Greece and Bronze Age Italy.

- The Treasure of Vălčitrăn: Production Technique and Toreutics.

\section{Technology of gold-, silver- and copper-alloy metalwork (Feinschmiedetechnik) by Birgit Bühler}

Since the year 2000, the "Feinschmiedetechnik" section of VIAS has been involved in the study of some of the most important finds of archaeological metalwork on presentday Austrian territory and in several prestigious research projects initiated by Austrian institutions. Hence, there exist long-term co-operations between this department of VIAS and numerous Austrian institutions focusing on cultural heritage and research, such as the Austrian Archaeological Institute (ÖAI), Kunsthistorisches Museum Wien (KHM), Naturhistorisches Museum Wien (NHM), and Bundesdenkmalamt Wien (BDA). Furthermore, technological research on gold-, silver- and copper-alloy metalwork at VIAS covers a wide range of archaeological periods, from the Bronze Age to the Late Medieval Period. Expertise on ancient and medieval metalworking techniques has been provided both for and in co-operation with a number of European institutions. Technological research on archaeological metalwork is not only crucial for any modern interpretation of archaeological finds - it is also a matter of cultural heritage, ensuring the survival of ancient metalworking techniques. In this context, the co-operation with David Schwarcz (ÖAI), who is a fully-trained goldsmith as well as an archaeologist, is extremely valuable.

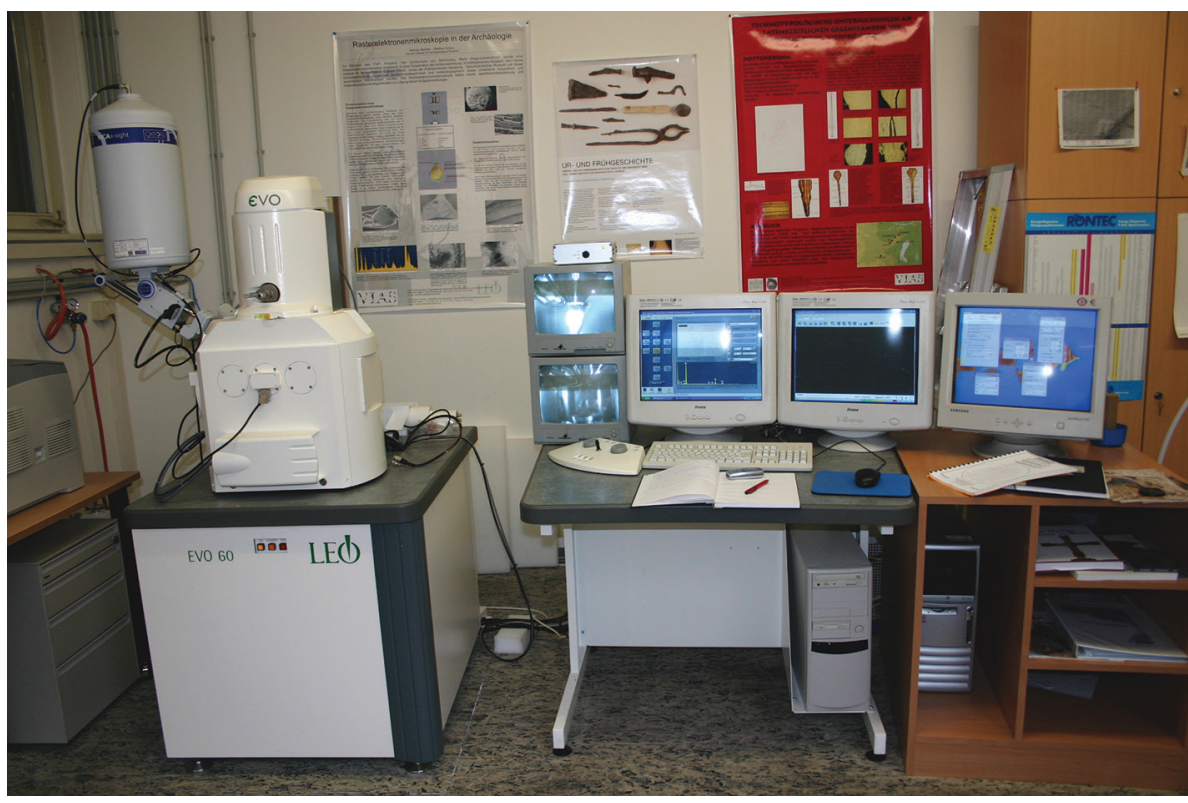

Figure 3. The VIAS Scanning Electron Microscope. Photo by M. Mehofer. 
Figure 4. Scanning electron microscope detail: Pelten-shaped hallmark on medallion jug no. 2 (after Hampel) from the Gold treasure from Nagyszentmiklós (today: Sânnicolau Mare, Romania), Kunsthistorisches Museum Vienna, Collection of Classical Antiquities, Inv. no. VII B 33. Photo: VIAS, M. Mehofer.

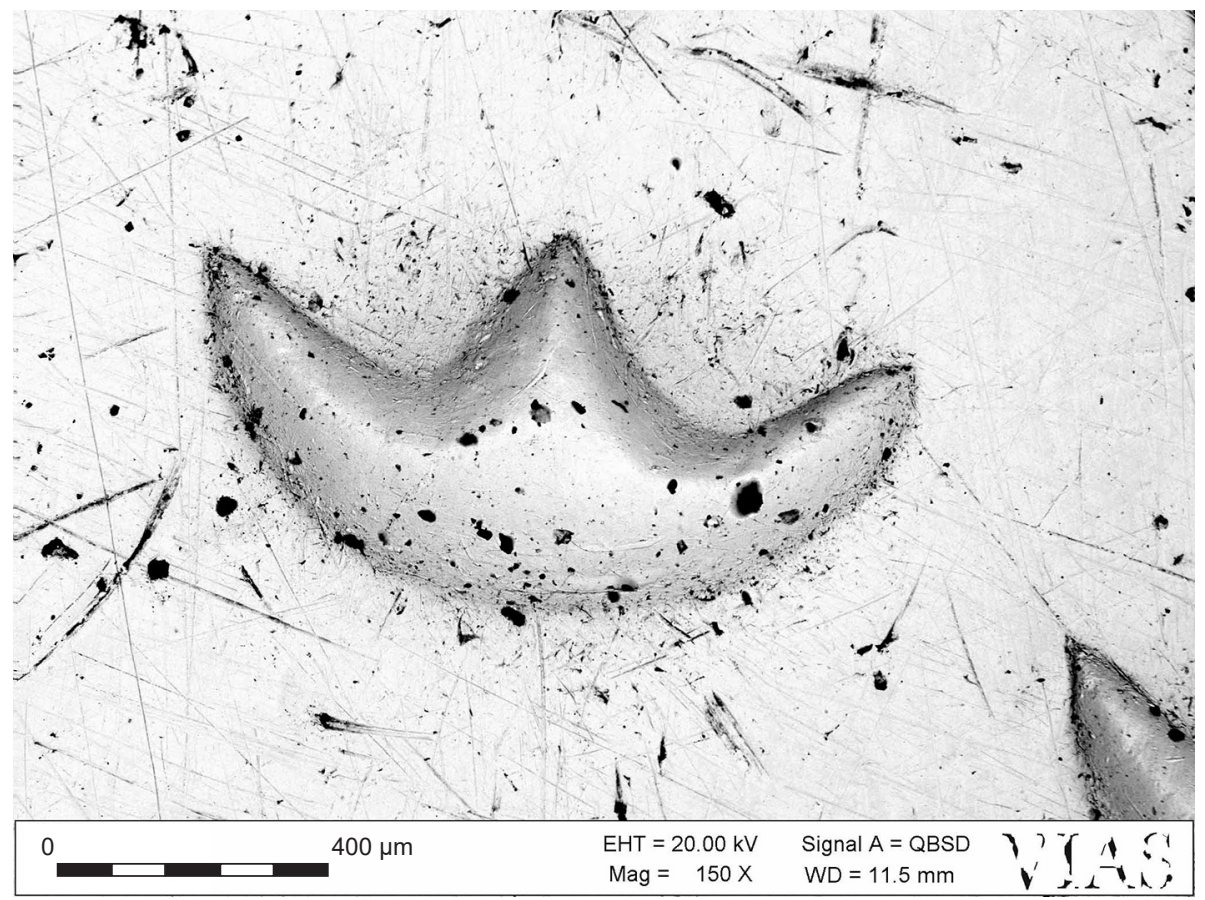

Birgit Bühler is an archaeologist and archaeometallurgist, specialising in early medieval archaeology, as well as in ancient goldsmithing techniques. Recent research focuses on cultural contacts between the Byzantine Empire and its "fringe cultures" (especially the Avar Empire), as well as on mechanisms of "technological transfer" (Bühler, 2014; Bühler and Freiberger, 2018; Bühler, 2020; Fecht and Bühler, 2020). In 2021-22, work on this research topic will be continued through participation in the FWF-Project "Does material matter? Similarities and differences in metal jewellery of the Early and Middle Byzantine Realm" directed by Andrea Pülz, ÖAI.

\section{Avar archaeology/Bioarchaeology}

Birgit Bühler is also planning to carry out interdisciplinary research relating to Avar archaeology. This will include a bioarchaeological study, conducted in cooperation with the Department of Evolutionary Anthropology at the University of Vienna, focusing on habitual activity patterns within the Avar population of Eastern Austria, in particular on the "horse riding syndrome".

\section{Ceramic investigation by Irmgard Hein}

The analysis of ceramics occupies a globally important place within archaeological research. Ceramics is the oldest material synthetically produced by human hand, which achieves a wide range of designs through its malleability (plasticity). Apart from the quantitatively overwhelming share of vessel ceramics, small objects (figures, figurines, amulets, pearls, etc.), up to masks or articles of daily use, such as furniture, floor coverings or wall tiles have been made of ceramics.
Within the framework of conventional archaeological studies on various goods and forms, as well as their contextual studies, the research interest over the past few years has been mainly the occurrence of Cypriot and other imported ceramics in Egypt (Hein 2018; 2019; 2020a).

In order to trace the origin of specific pottery wares, we have already demonstrated successfully the application of multiple geological and chemical analytical methods in the field of pottery analyses (Tschegg et al., 2008). The combination of various methods in the laboratory shows excellent results (Tschegg et al., 2009a; 2009b). Research into analytical techniques for ceramics also motivated us to organise the $11^{\text {th }}$ European Meeting of Ancient Ceramics in Vienna in 2011 (Hein et al., 2013).

Diverse analytical processes, which usually are destructive to the investigated sample and often depend on available laboratory conditions, cannot always be applied. With the recent acquisition of a pXRF device (Bruker TRACER G5) we now have the possibility to capture objects from museums (not only ceramics) or in countries where sample export is not possible. For the efficient use of the instrument, the development of a reference series/standard is currently in preparation to ensure a stable comparison of the measurement data obtained.

Due to often regionally-caused problems of access to the find material, or due to the difficulties of taking nondestructive samples for laboratory examinations, methods of digital image analysis have also been considered. The processing of digital images and the recognition of material has been developed in cooperation with colleagues from Mexico, P. Lopez and J. Lira (INAH and UNAM). The aim is to create standard patterns of ceramics (or other materials) from various regions, so that origins and technological transformations caused by firing and postdepostional 


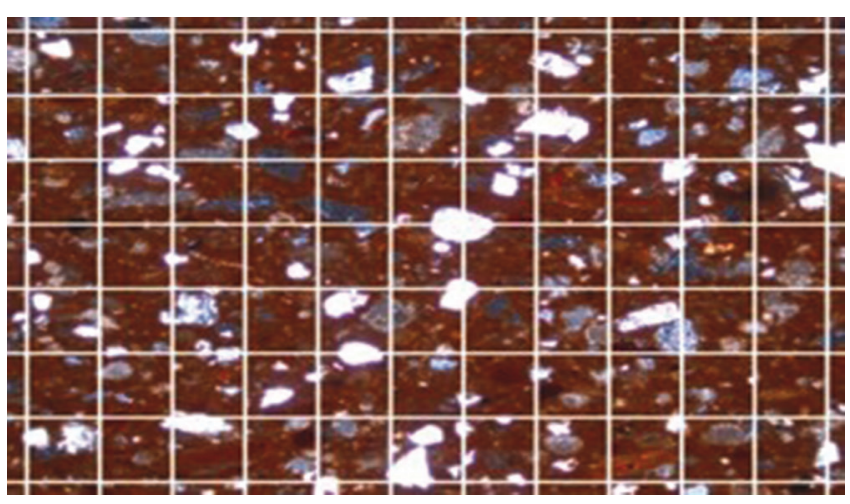

Figure 5. Image division of a ceramic thin section into panels for further analysis with a Gabor filter. Photo by I. Hein.

conditions can be traced by standardised, non-subjective procedures. The method utilizes digitized images of petrographic thin sections that are analysed in several steps using various programs for the recognition of ancient ceramics. The goal is to create statistical moments out of quantified particles via segmentation and granulometry. A series of test samples from Cyprus and Mexico, which are analytically investigated by other methods, has shown promising results (Lopez et al., 2015). Another study used various filters in order to analyse the textures of Cypriot and Egyptian ceramics (Hein et al., 2018).

The focus for future research within VIAS will be broadened by the use of pXRF. The possibility to quickly obtain analytical data in the field is a considerable advancement that will be expanded in future research projects.

\section{Digital archaeological documentation methods by Irmgard Hein}

In the development of standardised processes for the digital documentation of excavations, the focus, on the one hand, is on the development of new methodology for data acquisition in the field, subsequent data processing, visualisation and analysis, and, on the other hand, is also on the digitisation of old analogue excavation documentations and appropriate modern data visualisations. VIAS cooperates in this field with the LBI ArchPro.

A current project within VIAS, financed by the Anniversary Fund of the Austrian National Bank (AP 17916), deals with the post-processing of a section of the Austrian excavations in the north-eastern Nile Delta, Egypt. Traditional archaeological documentation material from an area of Tell el Dab'a from
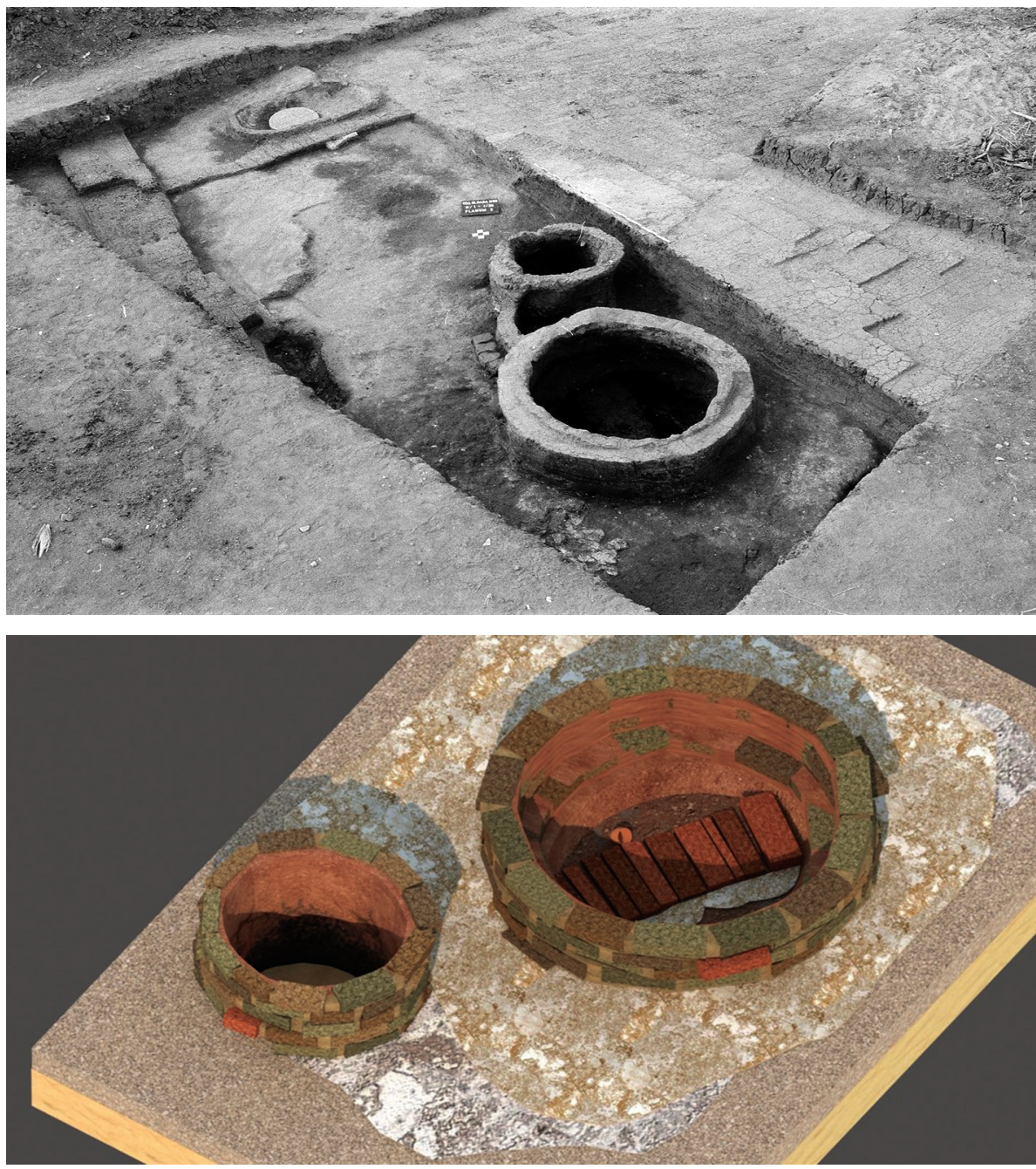

Figure 6. Field recording of two ovens from 'Ezbet Helmi, H/I-j/26 from 1990. Photo Tell el-Dab'a archive, ${ }^{\circ}$ ÖAI.

Figure 7. 3D-visualisation of the two oven features from 'Ezbet Helmi, H/I-j/26. Image Sandra Müller, ${ }^{\circ}$ Project Anniversary Fund AP 17916. 
the site of 'Ezbet Helmi is being digitalised. The basic documentation material comes from the excavations conducted in the years 1989-1995 by the Austrian Archaeological Institute Cairo under then excavation director Manfred Bietak. The site of Tell el-Dab'a is known as the urban area of the former capital of the Hyksos period Auaris.

The focus of the project is on the so-called small palace platform $\mathrm{F}$ from the early New Kingdom and the surrounding settlement remains. Due to the discovery of fragments of Minoan wall paintings, the excavation had attracted a great deal of attention during the fieldwork at the time, and various studies on the frescoes and individual find complexes have been published, but no overall analysis of the areas and features has been carried out to date. The project under the direction of Irmgard Hein, in cooperation with Sandra Müller (Hein and Müller, 2020b), is primarily dedicated to the clarification of the stratigraphy, the architectural remains, and the comprehensive inclusion of the find material by creating a GIS database (ESRI ArcMap) whose entries will be converted into 2.5-dimensional individual models of the features using ArcScene ( $c f$. Kucera et al., 2020). Furthermore, the data will be used for the stratigraphic evaluation within a Harris matrix, as well as for the 3D-visualisation of the palace area.

A further project dedicated to the post-processing of old excavation inventories is the recording of the magazine inventories from Karnak North (Egypt), from the treasury of Thutmosis I, which is being carried out in cooperation with the Institut français d'archéologie orientale in Cairo (project 17223, Karnak Nord: les archives, Hein, 2019b). This treasure house was excavated in the years 1970-1978 and the remains have been largely published by the excavators Jean
Jacquet and Helen Jacquet-Gordon. Within the framework of this project, which came about at the instigation of the Egyptian Department of Antiquities, those objects still in storage on site have been recorded since 2013 by digital photography and in digital lists for inclusion in a database. The finds include mainly ceramic vessels and diagnostic sherds, as well as relief fragments, other small finds and a few statue fragments. To date, about 28,000 photos are available for integration into an image database (Hein, 2020b). In addition, previously unpublished pieces, such as most of the non-ceramic finds, are documented by descriptions and occasionally drawings with the aim of publishing them.

Ongoing projects:

- Digital analysis and visualization of the $18^{\text {th }}$ Dynasty delta residence at Tell el-Dab'a, Egypt. [online]. https://vias.univie.ac.at/projekte/aktuell/tell-el-daba/.

- Les dépôts et archives de Karnak-Nord. Étude de mobilier archéologique et des fragments de relief. [online]. Institut français d'archéologie orientale du Caire. https://www.ifao.egnet.net/recherche/archeologie/ karnak-nord.

\section{Building archaeology by Gabriele Scharrer-Liska}

Within VIAS, building research with an archaeological focus is pursued as part of basic research. Archaeological (or historical) architectural research has a long tradition. It overlaps with many other historical/archaeological disciplines and can be considered as a sub-discipline of archaeology. Building research explores historical buildings with an archaeological-historical approach.
Figure 8. Torrenova, West wall of the Conventazzo (Byzantine Monastery). Photo by G. Scharrer-Liska.

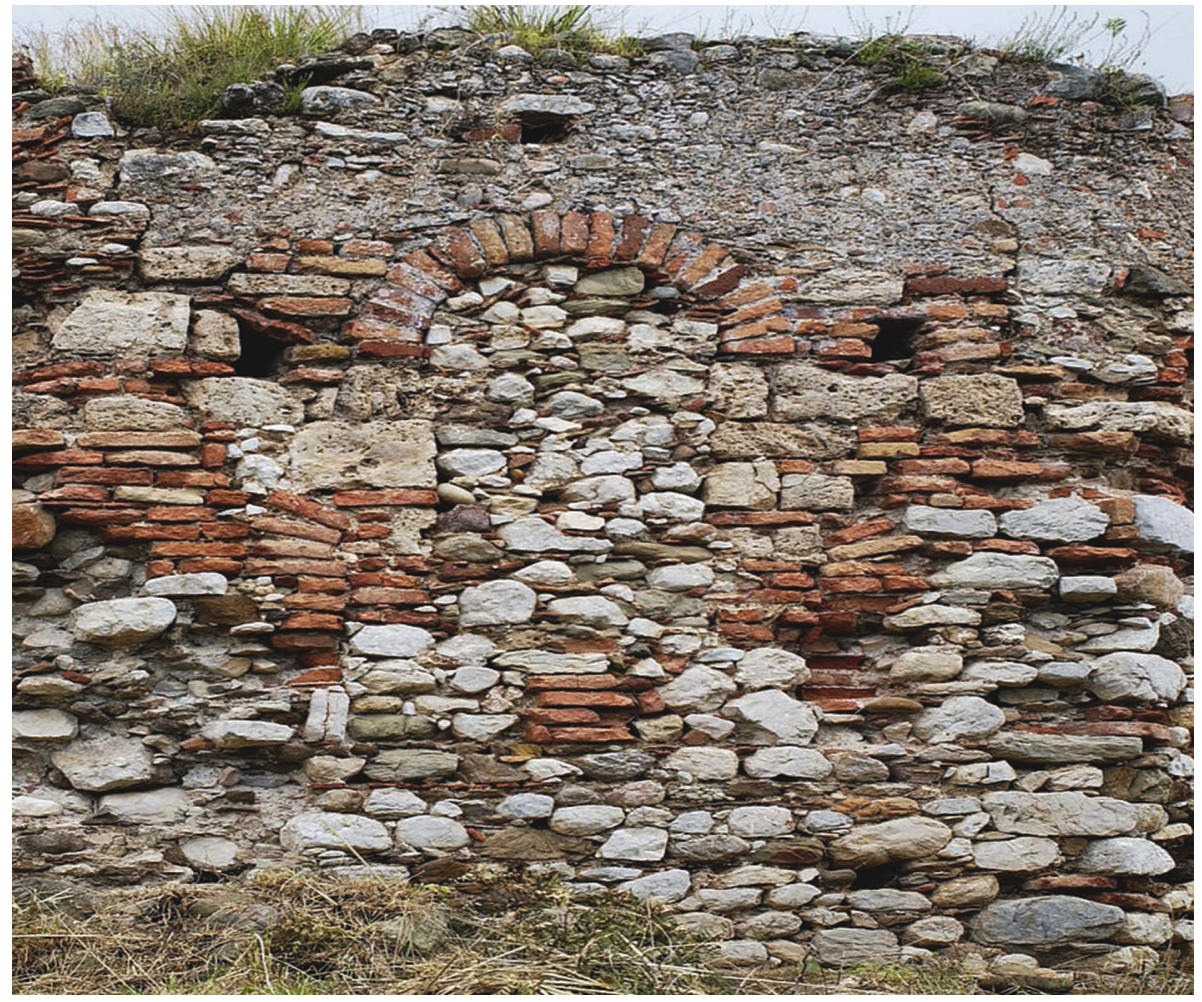


Building research employs predominantly non-destructive methods. This includes above all the documentation of buildings (construction survey) with the help of suitable methods. In addition to the written documentation, one of the most important aspects is the production of an oversize, which can be realised in the form of a classical hand measurement, a computer-aided hand measurement, or photogrammetry.

The aim of archaeological building research is to reconstruct building sequences and thus the history of a building as well as its function(s). As in the case of any archaeological-historical discipline, the goal of building research is to develop images of landscape-archaeological, economic-historical and social-historical topics in a continuous interdisciplinary discussion.

One of the recent projects within VIAS was the analysis and interpretation of the so-called Conventazzo, located on the north coast of Sicily (Italy). The building which probably has its roots in Late Antiquity is the only remains still above ground of the complex of the Norman monastery of San Pietro di Deca. Analysis and interpretation of the Conventazzo has been derived from the orthophotos and line drawings, but mostly, however, through careful observation and description of the object onsite. Similar to an archaeological excavation, the stratigraphy of the building has been described, involving the succession of the former construction activity, and has thus led to six main construction stages. The Conventazzo belongs to the type of the central building. Outside it has the shape of an octagon, inside - unbalanced to the exterior - the shape of a rotunda with niches. Generally, it can be noted that the type of the central building in Italy is based on (Late) Antiquity. In the $4^{\text {th }}$ to $5^{\text {th }}$ centuries this building type is characteristically for baptisteries and memorial chapels.

\section{Geophysical archaeological prospection on land and underwater by Immo Trinks and Wolfgang Neubauer}

VIAS comprises specialists for geophysical archaeological prospection and digital archaeological documentation methods, focussing on research and development into, and application of, magnetometry, ground-penetrating radar (GPR) measurements, terrestrial laser scanning, GIS-based integrated data interpretation, as well as virtual reality simulations and methods for archaeological stratigraphy documentation. VIAS possesses great expertise and a long history in the setup and application of highly-sensitive
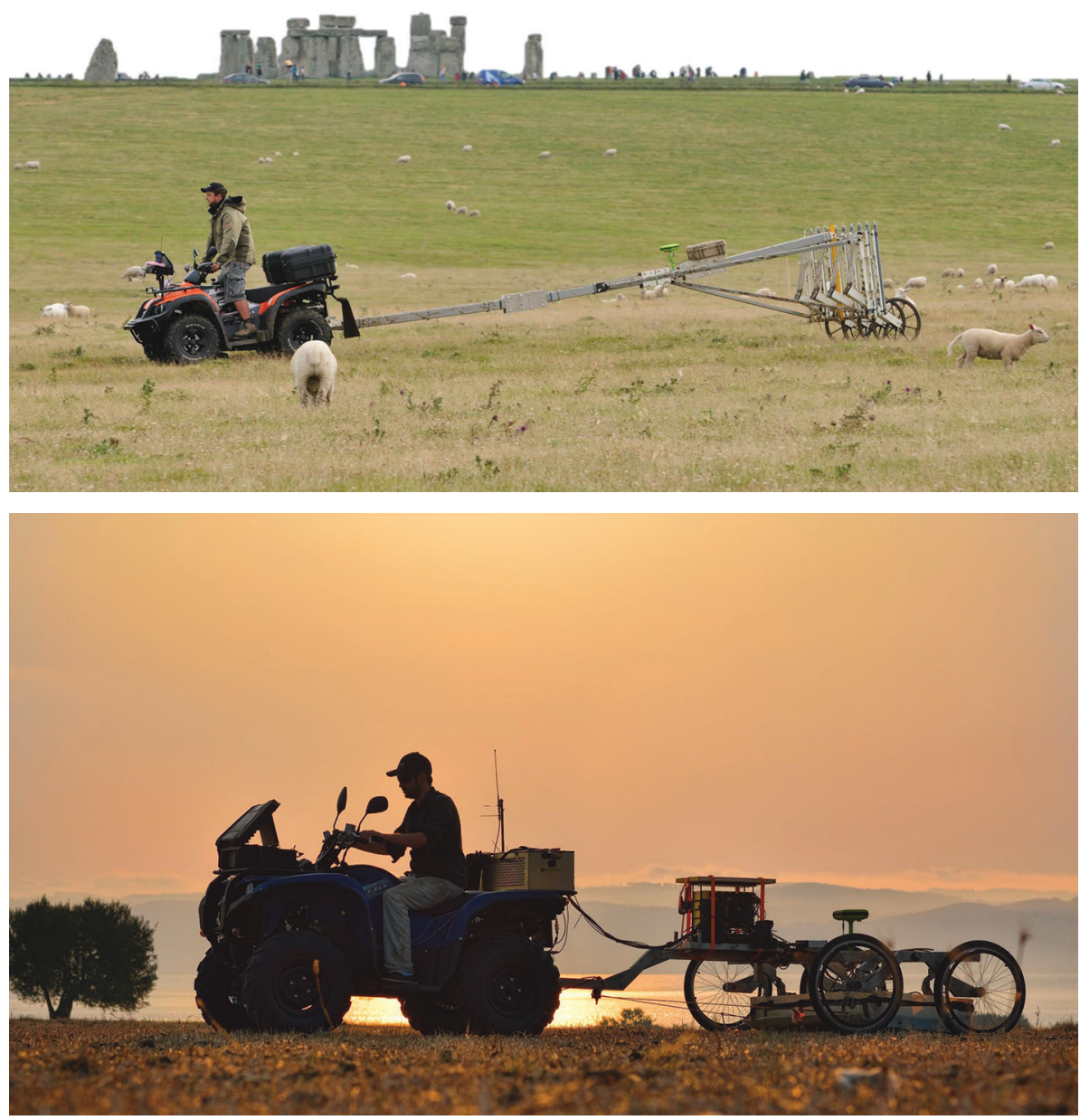

Figure 9. Magnetics: Motorised 10-channel magnetometer system used by the LBI ArchPro with support from VIAS during for large-area magnetic survey within the Stonehenge Hidden Landscape Project. Photo by G. Verhoeven, ${ }^{\circ}$ LBI Arch Pro.

Figure 10. GPR: A motorised 6-channel ground-penetrating radar system used in search of Etruscan remains at Bisenzio next to Lake Bolsena, Italy. Photo by G. Verhoeven, ${ }^{\circ}$ LBI Arch Pro. 
Figure 11. SONAR: The VIAS/LBIArchPro sonar survey boat for high-resolution underwater archaeological prospection of Lake Mondsee in Upper Austria. Photo by I. Trinks, ${ }^{\circ}$ LBI Arch Pro.

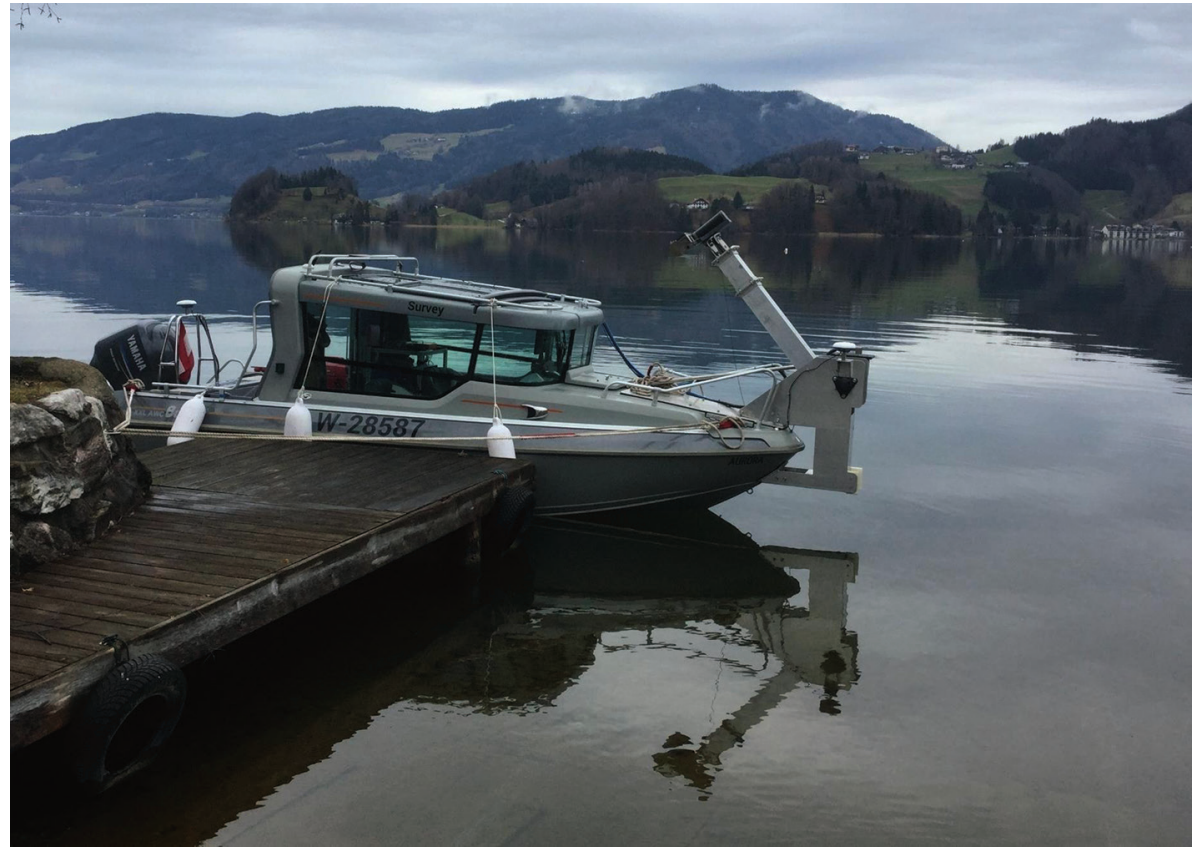

Cesium magnetometer array systems and has pioneered detailed archaeological GPR surveys and the custom development of highly-specialised, data-processing solutions in close cooperation with experts from the Zentralanstalt für Meteorologie und Geodynamik (ZAMG). In 2010, VIAS became an important founding partner of the Ludwig Boltzmann Institute for Archaeological Prospection and Virtual Archaeology (LBI ArchPro). Over the past decade, VIAS has significantly contributed to the research and development conducted by the LBI ArchPro, which resulted in substantial advancements regarding prospection efficiency and spatial sampling resolution regarding near-surface geophysical prospection surveys. Using motorised Fluxgate gradiometer systems and multichannel GPR antenna arrays, an enormous increase in coverage has been achieved, amounting in total to $44 \mathrm{~km}^{2}$ of very high-resolution magnetic prospection data and over $20 \mathrm{~km}^{2}$ of ultra-high-resolution GPR data being collected. Archaeological Prospection Case studies have revealed extraordinary archaeological discoveries in the framework of the Stonehenge Hidden Landscapes Project, the ArchPro Carnuntum Project (e.g. discovery of a school of gladiators), the discovery of the remains of two buried Viking ships in Norway, and monumental hall buildings at Borre National Park, amongst many others, resulting in the work of the LBI ArchPro featuring twice among the international annual top-10 archaeological discoveries. The successful terrestrial archaeological prospection approach has now been translated to extensive high-resolution underwater archaeological surveys involving a boat equipped with the latest multi-beam sonar and four-channel sediment sonar systems, specifically suited for detailed surveys in shallow water.

Together with the Institute for Prehistory and Historical Archaeology of the University of Vienna and ZAMG, an Initiative College for Archaeological Prospection (IC
ArchPro) has been established, which accommodates 15 international $\mathrm{PhD}$ candidates. The archaeological prospection data and resources shared by VIAS in the scientific partnership of the LBI ArchPro are outstanding and internationally unrivalled.

\section{Construction of prehistoric architectural models using methods of Experimental Archaeology by Wolfgang F.A. Lobisser}

"Archaeological parks will define the understanding of history of our children much more than all our special scientific writings together." (W. Gauer)

Since 2002, VIAS has spent time on planning, conceptualising and constructing archaeological open-air museums. The construction of houses and other buildings is conducted by using methods of Experimental Archaeology. To this purpose, it creates the possibility to gain new knowledge concerning prehistoric architecture, traditions and craft techniques. The term "archaeological open-air museum" defines projects that show rebuilt reconstructions of prehistoric architectural models, which can be houses, technical constructions, or complexes of agricultural or economic structures, as gardens and fields. Archaeological open-air museums classify the understanding of history for the broad public. Therefore, the increased responsibility of people planning and building such structures is obvious. The project partners and clients of VIAS are mostly museums and rural communes who wish to create tourist installations by showing prehistoric living situations, and thus providing educational opportunities to the visitors.

Over the past years, VIAS has conducted numerous archaeological experiments concerning prehistoric architecture, wood technology, the use of prehistoric tools, 


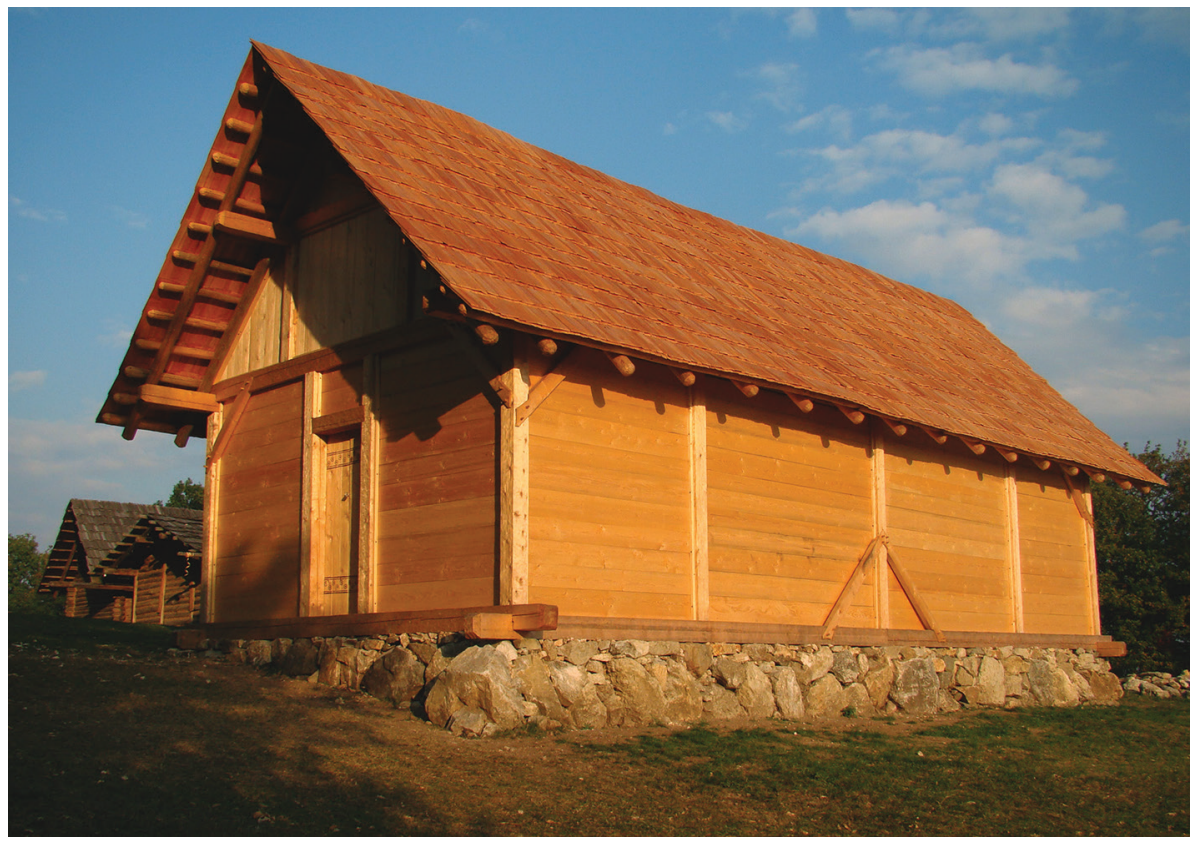

Figure 12. Reconstruction of a Celtic house. Schwarzenbach. Niederösterreich. Photo by W. Lobisser.

ceramic production, textile techniques, bone- and antlercarving, as well as leather- and stone-working. Many of these experimental works could be conducted during contracted archaeological research while erecting open-air structures, or producing show pieces and archaeological remakes, for exhibitions and presentations. VIAS can be contacted for undertaking or helping with any kind of serious archaeological experiment or open-air project. The main concept of an archaeological experiment is comparable to an experiment in natural sciences. First, it is of great importance to formulate a well-defined research question before starting an experiment. The question can evolve from excavations, historical text or portrayals. Each experiment has a classical course, which starts with the study of the history of the research itself. During the preparations for the experiment, ethnological and ethno-archaeological knowledge is compared and combined. The results are compared with existing theories, and if they differ, the theories have to be adapted or even changed. It is obvious that every experiment gives rise to a whole bunch of consecutive experiments that together enlarge our knowledge and cultural and historical approaches. Human beings with their problems, abilities and solutions are always in the focus of Experimental Archaeology.

\section{VIAS Bibliography}

BALASSE, M., RENAULT-FABREGON, L., GANDOIS, H., FIORILLO, D., GORCZYK, J., BACVAROV, K., and IVANOVA, M., 2020. Neolithic sheep birth distribution: Results from Nova Nadezhda (sixth millennium BC, Bulgaria) and a reassessment of European data with a new modern reference set including upper and lower molars. Journal of Archaeological Science, 118, 105-139. DOI: 10.1016/j. jas.2020.105139.

BALASSE, M., TRESSET, A., BĂLĂŞESCU, A., BLAISE, E., TORNERO, C., GANDOIS, H., FIORILLO, D., NYERGES, E., FRÉMONDEAU, D., BANFFY, E. and IVANOVA, M., 2017.
Sheep birth distribution in past herds: A review for prehistoric Europe ( $6^{\text {th }}$ to $3^{\text {rd }}$ millennia BC). Animal, 11(12), 2229-2236. DOI: 10.1017/ S1751731117001045.

BÜHLER, B., 2014. Der „Schatz" von Brestovac, Kroatien. Seine kulturellen Beziehungen und technologischen Aspekte. Monographien des Römisch-Germanischen Zentralmuseums Mainz 85, Mainz: Schnell $\&$ Steiner.

BÜHLER, B., 2020. Herstellungstechnische Studien zu byzantinischen Feinschmiedearbeiten aus Ephesos und Umgebung. In: A.M. Pülz, ed. Byzantinische Kleinfunde aus Ephesos. Forschungen in Ephesos XVIII/ 1, Wien, pp. 223-242. DOI: 10.1553/0x003b4926.

BÜHLER, B. and FREIBERGER, V., 2018. Die Ergebnisse der goldschmiedetechnischen und chemischen Untersuchungen. In: F. Daim, K. Gschwantler, G. Plattner, and P. Stadler, eds. Der Goldschatz von Sânnicolau Mare (ungarisch: Nagyszentmiklós). Monographien des Römisch-Germanischen Zentralmuseums Mainz 142. Teil 1. Mainz: Schnell \& Steiner, pp. 23-201.

CRAMP, L., ETHIER, J. UREM-KOTSOU, D., BONSALL, C., BORIC, D., BORONEANT, A., EVERSHED, R., PERIC, S., ROFFETSALQUE, R., WHELTON, H., and IVANOVA, M., 2019. Regional diversity in subsistence among early farmers in Southeast Europe revealed by archaeological pottery organic residues. Proceedings of the Royal Society B, 286, 20182347. DOI: 10.1098/rspb.2018.2347.

CZICHON, R. M., KLINGER, J., HNILA, P., MIELKE, D.P., BEHRENDT, S., BÖHM, H., BREUER, M., FORSTER, C., GRIGGS, C., KLEIN, M., KOCH, M., KUNST, G.K., LEHMANN, M., LORENTZEN, B., MANNING, S.W., MARKLEIN, K., PURSCHWITZ, C., RÖSSNER, C., TAPPERT, C. and VALSECCHI GILLMEISTER, M.A., 2019. Archäologische Forschungen am Oymaağaç Höyük/Nerik 2016-2018. Mitteilungen der Deutschen OrientGesellschaft zu Berlin, 151, 37-200.

DRAGANITS, E., DONEUS, M., GANSUM, T., GUSTAVSEN, L. NAU, E., TONNING, C., TRINKS, I., and NEUBAUER, W., 2015. The late Nordic Iron Age and Viking Age royal burial site of Borre in Norway: ALS- and GPR-based landscape reconstruction and harbour location at an uplifting coastal area. Quaternary International, 367, 96-110.

DRAUSCHKE， J., KÜHTREIBER， K., KÜHTREIBER， T., SCHARRER-LISKA, G. and VIDA, T., eds., 2018. Lebenswelten zwischen Archäologie und Geschichte. Festschrift für Falko Daim zu seinem 65. Geburtstag. Mainz: Monographien des RömischGermanischen Zentralmuseums, 150, 2018.

ETHIER, J., BÁNFFY, E., VUKOVIC, J., LESHTAKOV, K., BACVAROV, K., ROFFET-SALQUE, M., EVERSHED, R.P. and 
IVANOVA, M., 2017. Earliest expansion of animal husbandry beyond the Mediterranean zone in the sixth millennium BC. Scientific Reports 7(1), 7146. DOI: 10.1038/s41598-017-07427-x.

EICHERT, S., and MEHOFER, M., 2013. Recycelte Römer oder slawische Metallurgen? Interdisziplinäre Studien zur frühmittelalterlichen Buntmetallindustrie im Ostalpenraum. Archäologie Österreichs, 24(2), 46-54.

FECHT, M. and BÜHLER, B., 2020.Auswertung der herstellungstechnischen Untersuchung. In: M. Schulze-Dörrlamm, ed. Byzantinische Goldschmiedearbeiten im Römisch-Germanischen Zentralmuseum. Kataloge Vor- und Frühgeschichtlicher Altertümer 42, Mainz: Schnell \& Steiner 2020, pp. 165-193.

GABLER, M., TRINKS, I., NEUBAUER, W.P., NAU, E., ZITZ, T., HINTERLEITNER, A. and THORÉN, H., 2013. First large-scale geophysical archaeological prospection at Uppåkra. Acta Archaeologica Lundensio, 8, 191-207.

GAFFNEY, V., NEUBAUER, W., P. GARWOOD, G. GAFFNEY, C., LÖCKER, K., BATES, R., DE SMEDT, P., BALDWIN, E., CHAPMAN, H., HINTERLEITNER, A., WALLNER, M., NAU, E., FILZWIESER, R., KAINZ, J., TRAUSMUTH, T., SCHNEIDHOFER, P., ZOTTI, G., LUGMAYER, A., TRINKS, I. and CORKUM, A, 2018. Durrington walls and the Stonehenge Hidden Landscape Project 2010 2016. Archaeological Prospection, 25(3), 255-269.

GÁL, E. and KUNST, G.K., 2018. Pathological Observations on Mammalian Remains from the Roman Sanctuary at CarnuntumMühläcker (Austria). In: L. Bartosiewicz, and E. Gál, eds. Care or Neglect? Evidence of Animal Disease in Archaeology. Proceedings of the $6^{\text {th }}$ meeting of the Animal Palaeopathology Working Group of the International Council for Archaeozoology (ICAZ), Budapest, Hungary, 2016. Oxford: Oxbow, pp. 45-60.

GAVRANOVIĆ, M., and MEHOFER, M., 2016. Local forms and regional distributions. Metallurgical analysis of the Late Bronze Age objects from Bosnia. Archaeologia Austriaca, 100, 87-106. DOI: 10.1553/ archaeologia100s87.

GORI, M. and IVANOVA, M., 2017. Balkan Dialogues. Negotiating Identity in the Prehistoric Balkans. London: Routledge.

GRÖMER, K., LÖCKER, K., and MEHOFER, M., eds., 2001. Experimentelle Archäologie - Einen Versuch ist es wert, Archäologie Österreichs, 12, Wien.

HEIN, I., 2018. Second Thoughts on Cypriot Pottery and First Appearances. In: I. Forstner-Müller, and N. Moeller, eds. The Hyksos Ruler Khyan and the Early Second Intermediate Period in Egypt: Problems and Priorities of Current Research. Proceedings of the Workshop of the Austrian Archaeological Institute and the Oriental Institute of the University of Chicago, Vienna, July 4-5, 2014. Ergänzungshefte zu den Jahresheften des Österreichischen Archäologischen Institutes, Heft 17, pp. 125-142.

HEIN, I. 2019. Kapitel VII.F, Bichrome bemalte Waren. Kapitel VII.G, White Painted Waren und Imitationen. In: J. Helmbold-Doyé and A. Seiler, eds. Die Keramik aus dem Friedhof S/SA von Aniba (Unternubien): Funde aus Aniba. Zeitschrift für Ägyptische Sprache, Beihefte 8, Berlin/Boston: DeGruyter Verlag, pp. 376-388.

HEIN, I., 2019b. Les dépôts et archives de Karnak-Nord. Étude de mobilier archéologique et des fragments de relief. Institut français d'archéologie orientale du Caire. Consulté le 1 décembre 2020. Online: https://www. ifao.egnet.net/recherche/archeologie/karnak-nord.

HEIN, I., 2020a. Painted Pots from Pharaoh's Palace. In: A.R. Warfe, J.C.R. Gill, C.R. Hamilton, A.J. Pettman and D.A. Stewart, eds. Dust, Demons and Pots. Studies in Honour of Colin A. Hope. OLA, 289, pp. 257-268. Online: https://www.peetersleuven.be/detail.php?search_ key $=9789042941366 \&$ series number str=289\&lang=en.

HEIN, I., 2020b. "Karnak-Nord - Storerooms" [notice archéologique], Bulletin archéologique des Écoles françaises à l'étranger. Égypte, mis en ligne le 01 novembre 2020, consulté le 1 décembre 2020. DOI: 10.4000/ baefe. 1158 .

HEIN, I., BIRO, K., BUXEDA I GARRIGÓS, J., DAY, P., IONESCU, C., KILIKOGLOU, V., MAGGETTI, M., and WAKSMAN, Y., eds., 2013. Ancient Ceramics - Analysis and Components. Special issue of the Journal of Applied Clay Science, 82, Sept. 2013. Online: http://www. sciencedirect.com/science/journal/01691317/82.

HEIN, I. and MÜLLER, S., 2020. Digital analysis and visualization of the $18^{\text {th }}$ Dynasty delta residence at Tell el-Dab'a, Egypt. VIAS. University
Vienna. Viewed $1^{\text {st }}$ of December 2020. Online: https://vias.univie.ac.at/ projekte/aktuell/tell-el-daba/.

HEIN, I., ROJAS-DOMÍNGUEZ, A., ORNELAS, M., D’ERCOLE, G. and PELOSCHEK, L., 2018. Automated classification of archaeological ceramic materials by means of texture measures', Journal of Archaeological Science: Reports, 21, 921-928. DOI: 10.1016/j. jasrep.2017.12.032.

HOREJS, B. and MEHOFER, M., eds., 2014. Western Anatolia before Troy. Proto-Urbanisation in the $4^{\text {th }}$ Millennium BC? Proceedings of the International Symposium held at the Kunsthistorisches Museum Wien, Vienna, Austria, 21-24 November, 2012. Oriental and European Archaeology 1, Wien: Verlag der Österreichischen Akademie der Wissenschaften.

IVANOVA, M., 2020. Growing societies: an ecological perspective on the spread of crop cultivation and animal herding in Europe. In: K. Gron, L. Sørensen and P. Rowley-Conwy, eds. Farmers at the Frontier: A PanEuropean Perspective on Neolithisation. Oxford: Oxbow, pp. 7-44.

IVANOVA, M., ATHANASSOV, B., PETROVA, V., TAKOROVA, D. and STOCKHAMMER, P., 2018. Social Dimensions of Food in the Prehistoric Balkans. Oxford: Oxbow.

IVANOVA, M., DE CUPERE, B., ETHIER, J., and MARINOVA, E., 2018. Pioneer farming in southeast Europe during the early sixth millennium BC: Climate-related adaptations in the exploitation of plants and animals. PLOS ONE 13(5): e0197225. DOI: 10.1371/journal. pone. 0197225 .

JUNG, R., and MEHOFER, M., 2013. Mycenaean Greece and Bronze Age Italy: cooperation, trade or war? Archäologisches Korrespondenzblatt, 43, 175-193.

JUNG, R., MEHOFER, M., and PERNICKA, E., 2011. Metal Exchange in Italy from the Middle to the Final Bronze Age $\left(14^{\text {th }}-11^{\text {th }}\right.$ cent. B.C.E). In: P.B. Betancourt, and S.C. Ferrence, eds. Metallurgy: Understanding How, Learning Why. Festschrift J.D. Muhly. Prehistory Monographs, 29. Philadelphia: INSTAP Academic Press, pp. 231-248.

KUCERA, M., NEUBAUER, W., MÜLlER, S., NOVAK, M., TORREJÓN-VALDELOMAR, J., WALLNER, M., HINTERLEITNER, A., LENZHOFER, A., and TRAXLER, C., 2020. The Tell el-Daba Archaeological Information System: Adding the Fourth Dimension to Legacy Datasets of Long-Term Excavations (A Puzzle in 4D). In: E. Aspöck, S. Stuhec, K. Kopetzky, M. Kucera, eds. Old Excavation Data. What Can We Do? Proceedings of the Workshop held at $10^{\text {th }}$ ICAANE in Vienna, April 2016. OREA, 16. Wien: Österr. Akademie der Wissenschaften, pp.101-119. DOI: 10.1553/0x003bca0e.

KÜHTREIBER, T., RISY, R., SCHARRER-LISKA, G. and THEUNE, C., eds., 2020. Leben mit dem Tod: Der Umgang mit Sterblichkeit in Mittelalter und Neuzeit. Beiträge der internationalen Tagung in St. Pölten, 11. bis 15. September 2018.

KUNST, G.K., BÖHM, H. and CZICHON, R.M., 2020. Faunal Refits in Settlement Archaeology - a Case Study from a Hittite Temple. Jahreshefte des Österreichischen Archäologischen Instituts in Wien, 88. 131-142.

KUNST, G. K., JETTMAR, P. and SALZER, R., 2018, A Broken Skate and Scattered Skittles? Worked Bones from the Castle of Grafendorf. In: J. Drauschke, E. Kislinger, K. Kühtreiber, T. Kühtreiber, G. ScharrerLiska, and T. Vida, eds. Lebenswelten zwischen Archäologie und Geschichte: Festschrift für Falko Daim zu seinem 65. Geburtstag. Vol. 2. Monographien des Römisch-Germanischen Zentralmuseums, 150. Mainz: Verlag des Römisch-Germanischen Zentralmuseums, pp. 941952.

KUNST, G. K. and KÜHTREIBER, T., 2020. Frühe Nachweise des Truthuhns (Meleagris gallopavo) aus Österreich. In: P. Morgenstern, ed. Beiträge zur Archäozoologie und Prähistorischen Anthropologie, 12. Langenweißenbach: Verlag Beier \& Beran, pp.161-170.

KUNST, G.K. and PACHER, M., 2019. Brown bear remains in prehistoric and early historic societies: case studies from Austria. In: D. Nagel, and N. Kavcik-Graumann, eds. Festschrift zum 80. Geburtstag von emer. Univ.-Prof. Dr. Mag. Gernot Rabeder. Berichte der Geologischen Bundesanstalt, 132, pp. 89-121.

LOBISSER, W.F.A., 2017a. Das neue Modell einer eisenzeitlichen Schmiede im Freilichtbereich des Urgeschichtemuseums MAMUZ in Asparn an der Zaya und Überlegungen zu ihrer Ausstattung, In: F. Pieler, and P. Trebsche, eds. Beiträge zum Tag der Niederösterreichischen Landesarchäologie 2017, Festschrift für Ernst Lauermann, Katalog des 
Niederösterreichischen Landesmuseums Neue Folge 541. Asparn an der Zaya: Bösmüller Print Managment GesmbH \&Co.KG, pp. 38-56.

LOBISSER, W.F.A., 2017b. Die Geschichte der archäologischen Architekturmodelle im Freilichtbereich des niederösterreichischen Museums für Urgeschichte - MAMUZ - in Asparn an der Zaya von den Anfängen bis zur Gegenwart. Experimentelle Archäologie in Europa, 16, 180-195.

LOBISSER, W.F.A., 2018a. Experimentalarchäologische Modellbauten von Grubenhäusern im Maßstab 1:1 auf der Basis von archäologischen Befunden aus dem 1. Jahrtausend nach Christus. In: E. Nowotny, M. Obenaus and S. Uzunoglu-Obenaus, eds. 50 Jahre Archäologie in Thunau am Kamp - Festschrift für Herwig Friesinger, Archäologische Forschungen in Niederösterreich 5. Amt der Niederösterreichischen Landesregierung, Wien-Stockerau: Bösmüller Print Managment, pp. 262-274.

LOBISSER, W.F.A., 2018b. Man muss das Eisen schmieden solange es heiß ist - Das neue Modell einer keltischen Schmiede im MAMUZ in Niederösterreich. Experimentelle Archäologie in Europa, 17, 158-73.

LOBISSER, W.F.A., 2019a. Das neue Modell eines großen hallstattzeitlichen Hallenhauses in Mitterkirchen im Machland - Betrachtungen zu Ressourcen, Werkzeugen, Arbeitstechniken, Holzverbindungen und zu Arbeitsaufwand, In: R. Karl, J. Leskovar, eds. Interpretierte Eisenzeiten - Fallstudien, Methoden, Theorie; Tagungsbeiträge der 8. Linzer Gespräche zur interpretativen Eisenzeitarchäologie, Studien zur Kulturgeschichte von Oberösterreich, Folge 49. Linz, pp. 321-358.

LOBISSER, W.F.A., 2019b. VIAS - Aus dem Laboratorium der Experimentellen Archäologie in Österreich. Plattform - Zeitschrift des Vereins für Pfahlbau und Heimatkunde e.v., 25-27, 54-58.

LOBISSER, W.F.A., 2019c. Zum Nachbau der frühbronzezeitlichen Proviantdose vom Lötschenpass, Berner Oberland, Schweiz. Plattform Zeitschrift des Vereins für Pfahlbau und Heimatkunde e.v., 25-27, 63-67.

LOBISSER, W.F.A., 2019d. Zur experimentalarchäologischen Herstellung eines Einbaums aus Eichenholz mit Werkzeugen, Methoden und Techniken der Bronzezeit. Experimentelle Archäologie in Europa, 18, 153-170.

LOBISSER, W.F.A., 2020a. Das keltische Freilichtmuseum von Schwarzenbach in der Buckligen Welt in Niederösterreich und die experimentalarchäologische Errichtung von zwei neuen eisenzeitlichen Hausmodellen. Experimentelle Archäologie in Europa, 19, 125-141.

LOBISSER, W.F.A., 2020b. Experimentalarchäologische Studien zum Bau von Holzhäusern mit eisenzeitlichen Werkzeugtypen - Das keltische Freilichtmuseum Schwarzenbach in der Buckligen Welt in Niederösterreich, Res Montanarum, 60, 1-11.

LOBISSER, W.F.A., and KERN, D., 2017. Lanze, Pfriem und Muschelschmuck - Experimentelle Nachbauten von Objekten aus tierischen Rohstoffen nach Originalen aus endneolithischen Gräbern des Unteren Traisentales. Archaeologia Austriaca, 101, 45-71.

LOBISSER, W.F.A., and LESKOVAR, J., 2017. Vom Grabungsbefund zum Hausgrundriss auf dem Bauplatz: Überlegungen zur Planung und Erstellung von Hausgrundrissen in der Eisenzeit in Bezug auf das neue große Hallenhausmodell im archäologischen Freilichtmuseum Mitterkirchen, In: R. Karl and J. Leskovar, eds. Interpretierte Eisenzeiten: Fallstudien - Methoden - Theorien, Tagungsbeiträge der 7. Linzer Gespräche zur interpretativen Eisenzeitarchäologie, Studien zur Kulturgeschichte von Oberösterreich, Folge 47. Linz: Oberösterreichisches Landesmuseum, pp. 323-336.

LOBISSER, W.F.A., and LESKOVAR, J., 2018. Die experimentalarchäologische Errichtung der neuen HerrInnenhalle von Mitterkirchen an der Donau im oberösterreichischen Machland. Experimentelle Archäologie in Europa, 17, 140-157.

LOPEZ, P., LIRA, J. and HEIN, I., 2015. Discrimination of Ceramic Types Using Digital Image processing by means of morphological filters. Archaeometry, 57(1), 146-162. DOI: 10.1111/arcm.12083.

MEHOFER, M., 2014a. Rasterelektronenmikroskopische Analysen an Objekten des Wiener Neustädter Schatzfundes. In: N. Hofer, ed., Der Schatzfund von Wiener Neustadt. Horn: Verlag Ferdinand Berger, pp. 40-72.

MEHOFER, M., 2014b. A note on the copper working remains from Stratum 2 at Hala Sultan Tekke, Cyprus. In: P. M. Fischer and T. Bürge, eds. Opuscula, 7. p. 75

MEHOFER, M., 2014c. Metallurgy during the Chalcolithic and the
Beginning of the Early Bronze Age in Western Anatolia. In: B. Horejs, and M. Mehofer, eds. Western Anatolia before Troy - Proto-Urbanisation in the $4^{\text {th }}$ millennium BC. Proceedings of the International Symposium held at the Kunsthistorisches Museum Wien, Vienna, Austria, 21-24 November 2012. Oriental and European Archaeology, 1, Wien, pp. 463 490. Online: http://austriaca.at/7761-6inhalt?frames=yes.

MEHOFER, M., 2015. Guss- und Schmiedetechnik der Bronzezeit - ein Überblick. In: T. Stöllner, K. Oeggl, eds. Bergauf Bergab. 10.000 Jahre Bergbau in den Ostalpen. Wissenschaftlicher Beiband zur Ausstellung im Deutschen Bergbau-Museum Bochum vom 31.10.2015 - 24.04.2016. und im Vorarlberg Museum Bregenz vom 11.06.2016 - 26.10.2016. Veröffentlichungen aus dem Deutschen Bergbau-Museum Bochum, 207, Rahden/Westf.: Verlag Marie Leidorf, pp. 233-238.

MEHOFER, M., 2016. Çukuriçi Höyük - Ein Metallurgiezentrum des frühen 3. Jts. v. Chr. in der Westtürkei, In: M. Bartelheim, B. Horejs and R. Krauss, eds. Von Baden bis Troia. Ressourcennutzung, Metallurgie und Wissenstransfer, OREA, 3, Rahden/Westf.: Verlag Marie Leidorf, pp. 359-374.

MEHOFER, M., and JUNG, R., 2017. Weapons and Metals - Interregional Contacts between Italy and the Eastern Mediterranean during the Late Bronze Age. In: P.M. Fischer and T. Bürge, eds. "Sea peoples" Up-toDate. New research on transformations in the Eastern Mediterranean in the 13th-11th centuries BCE. Denkschriften der Gesamtakademie, 81. Contributions to the Chronology of Eastern Mediterranean, 35, Wien: Verlag der Österreichischen Akademie der Wissenschaften, pp. 389-400.

NEUBAUER, W., GUGL, C., SCHOLZ, M., VERHOEVEN, G., TRINKS, I., LÖCKER, K., DONEUS, M., SAEY, T., and VABEIRVENNE, M., 2014. The discovery of the school of gladiators at Carnuntum, Austria. Antiquity, 88, 173-190.

PENKOVA, P., and MEHOFER, M., 2017. Der Schatzfund von Vălčitrăn - Herstellungstechnik und Toreutik. In: S. Haag, Ch. Popov, B. Horejs, S. Alexandrov, and G. Plattner, eds. Das erste Gold - Ada Tepe: Das älteste Goldbergwerk Europas. KHM Wien Sonderaustellung 2017. Wien: Kunsthistorisches Museum. pp. 81-86.

PERNICKA, E., NESSEL, B., MEHOFER, M. and SAFTA, E., 2016. Lead isotope analyses of metal objects from the Apa hoard and other Early and Middle Bronze Age items from Romania, Archaeologia Austriaca, 100, 57-86.

POHL, W. and MEHOFER, M., eds., 2010. Archaeology of Identity - Archäologie der Identität. Forschungen zur Archäologie des Mittelalters, 17(406). Wien: Verlag der Österreichischen Akademie der Wissenschaften. Online: https://verlag.oeaw.ac.at/kategorie 30.ahtml.

SCHARRER-LIŠKA, G., 2019. Buchrezension: Elisabeth Nowotny, Thunau am Kamp - Das frühmittelalterliche Gräberfeld auf der Oberen Holzwiese. Beiträge zur Mittelalterarchäologie in Österreich, 35, 394 396.

SCHARRER-LISKA， G., CICHOCKI, O. and WILTSCHKESCHROTTA, K., 2015, Wooden coffins in the Avar-period cemetery in Frohsdorf, Lower Austria. Open Archaeology, 1(1), 54-78.

SCHARRER-LISKA, G. and GREIFF, S., 2018. Ein awarenzeitliches Glasgefäß aus dem Gräberfeld von Frohsdorf (A) und sein kulturhistorischer Kontext. In: J. Drauschke, K.E.K. Kühtreiber, T. Kühtreiber, G. Scharrer-Liska and T. Vida, eds. Lebenswelten zwischen Archäologie und Geschichte. Festschrift für Falko Daim zu seinem 65. Geburtstag. Mainz: Monographien des Römisch-Germanischen Zentralmuseums, 150, pp. 997-1012.

TONNING, C., SCHNEIDHOFER, P., NAU, E., GANSUM, T., LIA, V., GUSTAVSEN, L., FILZWIESER, R., WALLNER, M., KRISTIANSEN, M., NEUBAUER, W., PAASCHE, K. and TRINKS, I. 2020. Halls at Borre: the discovery of three large buildings at a Late Iron and Viking Age royal burial site in Norway. Antiquity, 94(373), $145-163$

TRINKS, I. and HINTERLEITNER, A., 2020. Beyond Amplitudes: Multi-Trace Coherence Analysis for Ground-Penetrating Radar Data Imaging. Remote Sensing, 12(10), 1583.

TRINKS, I., HINTERLEITNER, A., NEUBAUER, W., NAU, E., LÖCKER, K., WALLNER, M., GABLER, M., FILZWIESER, R., WILDING, J., SCHIEL, H., JANSA, V., SCHNEIDHOFER, P., TRAUSMUTH, T., SANDICI, V., RUSS, D., FLÖRY, S., KAINZ, J., KUCERA, M., VONKILCH, A., TENCER, T., GUSTAVSEN, L., KRISTIANSEN, M., BYE-JOHANSEN, L.-M., TONNING, 
C., ZITZ, T., PAASCHE, K., GANSUM, T. and SEREN, S., 2018. Large-area high-resolution ground-penetrating radar measurements for archaeological prospection. Archaeological Prospection, 25(3), 171-195.

TRINKS, I., NEUBAUER, W. and DONEUS, M., 2012. Prospecting Archaeological Landscapes. In: M. Ioannides, D. Fritsch, J. Leissner, R. Davies, F. Remondino and R. Caffo, eds. Progress in cultural heritage preservation. $4^{\text {th }}$ International Conference, EuroMed 2012: Limassol, Cyprus, October 29-November 3, 2012: Proceedings. Berlin, Heidelberg: Springer, pp. 21-29.

TRINKS, I., NEUBAUER, W. and HINTERLEITNER, A., 2014. First High-resolution GPR and Magnetic Archaeological Prospection at the Viking Age Settlement of Birka in Sweden. Archaeological Prospection, 21(3), 185-199.

TRINKS, I., NEUBAUER, W., TAYLOR, T., WALLNER, M., LÖCKER, K. and LESKOVAR, J., 2019, High-resolution underwater archaeological prospection of Upper Austrian pile dwellings and lakes using multibeam and sediment sonar. In: J. Bonsall, ed., New Global Perspectives on Archaeological Prospection, $13^{\text {th }}$ International Conference on Archaeological Prospection 28 August - 1 September 2019, Sligo - Ireland. Oxford: Archaeopress Publishing Ltd. pp. 21-23.

TSCHEGG, C., HEIN, I. and NTAFLOS, T., 2008. State of the art multi-analytical geoscientific approach to identify Cypriot Bichrome
Wheelmade Ware reproduction in the Eastern Nile delta (Egypt), Journal of Archaeological Science, 35, 1134-1147. DOI: 10.1016/j. jas.2007.08.014.

TSCHEGG, C., NTAFLOS, T. and HEIN, I., 2009a. Integrated geological, petrologic and geochemical approach to establish source material and technology of Late Cypriot Bronze Age Plain White ware ceramics. Journal of Archaeological Science, 36, 1103-1114. DOI: 10.1016/j. jas.2008.12.004

TSCHEGG, C., NTAFLOS, T. and HEIN, I., 2009b. Thermally triggered two-stage reaction of carbonates and clay during ceramic firing - a case study on Bronze Age Cypriot ceramics. Applied Clay Science, 43, 69-78. DOI: 10.1016/j.clay.2008.07.029

VALAMOTI, S.M., CHONDROU, D., BEKIARIS, T., NINOU, N., ALONSO, N., IVANOVA, M., LAPARIDOU, S., MCNAMEE, C., PALOMO, I.A., PRATS, G., PROCOPIOU H. and TSARTSIDOU, G., 2020. Plant foods, stone tools and food preparation in prehistoric Europe: an integrative approach in the context of ERC funded project PLANTCULT. Journal of Lithic Studies 7(3). DOI: 10.2218/j1s.3095.

ZECHMEISTER, H.G., KROPIK, M., POPOVTSCHAK, M. and SCHARRER-LIŠKA, G., 2019. Bryophytes in a latrine as indicators of climate change in the $17^{\text {th }}$ century. Vegetation History and Archaeobotany, 28(5), 575-581. 
